\title{
MODEL PEMBELAJARAN DIRECT INSTRUCTION DENGAN METODE DEMONSTRASI SEBAGAI UPAYA UNTUK MENINGKATKAN PRESTASI BELAJAR PENDIDIKAN JASMANI OLAHRAGA DAN KESEHATAN SISWA KELAS III SEMESTER I TAHUN PELAJARAN 2018/ 2019 SD NEGERI 22 DAUH PURI
}

\author{
Oleh \\ I Gst Ayu Nyoman Alit \\ SD Negeri 22 Dauh Puri \\ gustiayualit0110@gmail.com
}

diterima 20 Maret 2019, direvisi 25 Maret 2019, diterbitkan 29 April 2019

\begin{abstract}
ABSTRAK
Penelitian ini dilaksanakan di SD Negeri 22 Dauh Puri di Kelas III yang prestasi belajar pendidikan jasmani olah raga dan kesehatan masih rendah. Tujuan penulisan penelitian tindakan kelas ini adalah untuk mengetahui apakah model Direct Instruction dengan metode Demonstrasi dapat meningkatkan prestasi belajar siswa. Metode pengumpulan datanya adalah tes prestasi belajar. Metode analisis datanya adalah deskriptif. Hasil yang diperoleh dari penelitian ini adalah model Direct Instruction dengan metode demonstrasi dapat meningkatkan prestasi belajar siswa. Ini terbukti dari hasil yang diperoleh 63,43 pada pada awalnya setelah diberikan tindakan pada siklus I meningkat menjadi 68,14 dan pada siklus II meningkat lagi menjadi 76,09. Kesimpulan yang diperoleh dari penelitian ini adalah model Direct Instruction dengan metode demonstrasi dapat meningkatkan prestasi belajar pendidikan jasmani olah raga dan kesehatan siswa kelas III semester I Tahun Pelajaran 2018/2019 SD Negeri 22 Dauh Puri.
\end{abstract}

Kata Kunci: Model Pembelajaran Direct Instruction, Metode Demonstrasi, Prestasi Belajar, Pendidikan Olahraga, Pendidikan Dasar

\section{PENDAHULUAN}

Pendidikan jasmani dan olahraga merupakan sebuah inventasi jangka panjang dalam upaya meningkatkan mutu sumber daya manusia, oleh karena itu jasmani dan olahraga terus ditingkatkan dan dilakukan dengan kesabaran dan keikhlasan. Oleh karena itu, pendidikan jasmani dan olahraga terus ditingkatkan dan dilakukan dengan kesabaran dan keikhlasan. Tujuan pendidikan jasmani dan olahraga di sekolah adalah membantu siswa untuk meningkatkan kesegaran jasmani dan kesehatannya melalui pengenalan dan penanaman sikap positip, serta kemampuan gerak siswa dan berbagai aktivitas jasmani agar dapat 1. Tercapainya pertumbuhan dan perkembangan jasmani khususnya tinggi dan berat badan secara harmonis.

2. Terbentuknya sikap dan perilaku seperti; displin, kejujuran, kerjasama 
serta mengikuti peraturan dan ketentuan yang berlaku. 3 . Menyenangi aktivitas jasmani yang dapat di pakai untuk mengisi waktu luang serta kebiasaan hidup sehat.

4. Tersalurnya hasrat untuk bergerak dan tercapainya gerakan yang benar.

5. Meningkatkan kesehatan, kesegaran jasmani, dan ketrampilan gerak dasar.

Dalam proses pembelajaran yang berlangsung, untuk dapat mencapai tujuan yang maksimal seperti yang diharapkan harus terjadi komunikasi aktif antara guru selaku penyampai informasi dengan siswa sebagai penerima informasi atau pengetahuan. Komunikasi yang akan dijalin oleh guru selaku agen dalam pembelajaran harus dimulai dengan perencanaan yang baik, sehingga alur pembelajaran yang dilakukan dapat berjalan secara sistematis dan terarah. Seperti yang dinyatakan Hamzah B Uno (dalam Yamin dan Maisah, 2009: 123) bahwa istilah pembelajaran memiliki hakkat perencanaan atau perancangan (desain) sebagai upaya untuk membelajarkan siswa. Itulah sebabnya siswa-siswa tidak hanya berinteraksi dengan guru sebagai salah satu sumber belajar, tetapi mungkin berinteraksi dengan keseluruhan sumber belajar yang dipakai untuk mencapai tujuan pembelajaran yang diinginkan. Oleh karena itu, pembelajaran yang terjadi memusatkan perhatian pada bagaimana membelajarkan siswa dan bukan pada apa yang dipelajari siswa.

Untuk dapat membelajarkan siswa sesuai apa yang diharapkan, guru harus didukung dengan pengetahuan dan pemahaman standar yang mesti dikuasai sesuai metodik dan didaktik, agar dapat mengelola secara profesional mata pelajaran yang diampunya. Kompetensi pedagogik yang dimaksud menurut
Mulyasa, (2011: 75) sekurangkurangnya meliputi: a) pemahaman wawasan atau landasan kependidikan; b) pemahaman terhadap peserta didik; c) pengembangan kurikulum/silabus; d) perancangan pembelajaran; e) pelaksanaan pembelajaran yang mendidik dan dialogis; f) pemanfaatan teknologi pembelajaran; g) evaluasi hasil belajar; dan $h$ ) pengembangan peserta didik untuk mengaktualisasikan berbagai potens yang dimilikinya.

Harapan nyata yang diinginkan di lapangan terkadang tidak selalu sejalan.Banyak faktor yang menjadi penyebab tidak terwujudnya harapan tersebut, seperti: kurangnya kemauan guru mengembangkan model pembelajaran, kemampuan guru memahami inti pembelajaran, kemampuan guru melaksanakan teoriteori pembelajaran terbaru, kemampuan guru memahami karakteristik peserta didik, kelengkapan sarana prasarana yang ada di sekolah, kemampuan anak mengikuti proses pembelajaran, dan lain-lain. Faktor-faktor yang disebutkan tersebut sangat berpengaruh terhadap pencapaian hasil tes yang diberikan pada siswa kelas III semester I Tahun Pelajaran 2018/2019 di SD Negeri 22 Dauh Puri ternyata baru mencapai nilai rata-rata 63,43 dengan prosentase ketuntasan belajar sebesar 31,70 \%

Mengatasi kesenjangan antara harapan dengan kenyataan di lapangan,memotivasi peneliti sebagai guru kelas III di SD Negeri 22 Dauh Puri mengupayakan peningkatan prestasi belajar Pendidikan jasmani olah raga dan Kesehatan dengan menerapkan model Direct Instruction menggunakan modode demonstrasi. Model pembelajaran langsung dipilih karena dalam pelajaran Pendidikan 
jasmani olah raga dan kesehatan materinya berupa suatu proses yang berkelanjutan dan sulit dipelajari sendiri oleh siswa sehingga perlu dipelajari secara bertahap (selangkah demi selangkah) dengan bantuan langsung dari guru. Arends (dalam Trianto,2009:41) yang menyebutkan bahwa Model pembelajaran langsung adalah salah satu pendekatan mengajar yang dirancang khusus untuk menunjang proses belajar siswa yang berkaitan dengan pengetahuan deklaratif dan pengetahuan prosedural yang terstruktur dengan baik yang dapat diajarkan dengan pola kegiatan yang bertahap, selangkah demi selangkah. Dengan tindakan yang seperti itu diharapkan prestasi belajar peserta didik akan dapat ditingkatkan.

\section{METODE}

Penelitian dilaksanakan di SD

Negeri 22 Dauh Puri kecamatan Denpasar Utara. Penelitian ini merupakan penelitian tindakan kelas. Dengan subjek Penelitian semua siswa kelas.III Semester I Tahun Pelajaran 2018/2019 SD Negeri 22 Dauh Puri. Objek penelitian adalah peningkatan prestasi belajar pendidikan jasmani olah raga dan kesehtan siswa kelas III semester I Tahun Pelajaran 2018/2019 SD Negeri 22 Dauh Puri. Penelitian ini dilakukan dari bulan Juli sampai bulan oktober 2018. Data dikumpulkan dengan metode tes adalah metode yang digunakan untuk mengumpulkan data dalam penelitian ini Adalah tes prestasi belajar. Data dianalisis dengan metode deskriptif. Untuk data kuantitatif dianalisis dengan mencari mean, median, modus, membuat interval kelas dan melakukan penyajian dalam bentuk tabel dan grafik. Indikator keberhasilan penelitian yang diusulkan dalam penelitian ini pada siklus I mencapai nilai rata-rata 70,00 dengan ketuntasan belajar $80 \%$ dan pada siklus II mencapai nilai rata-rata 75,00 atau lebih dengan ketuntasan belajar minimal $80 \%$.

\section{KAJIAN PUSTAKA}

\section{A. Model Direct Instruction}

Model pengajaran langsung ini dirancang khusus untuk menunjang proses belajarsiswa yang berkaitan dengan pengetahuan prosedural dan pengetahuan deklaratif yangterstruktur dengan baik, yang dapat diajarkan dengan pola kegiatan yang bertahap,selangkah demi selangkah. Hal ini sesuai dengan pendapat Arends (2001), yang menyatakan bahwa "The direct instruction model was specifically designed to promote student learning of procedural knowledge and declarative knowledge that is well structured and can be taught in a stepby-stepfashion." Sedangkan Carin (1993) berpendapat bahwa direct instruction secarasistematis menuntun dan membantu siswa untuk melihat hasil belajar dari masing-masingtahap demi tahap.sementara Kardi (2001) mendefinisikan "Model Pembelajaran Langsung (MPL)adalah suatu strategi pembelajaran yang digunakan untuk mengajarkan konsep danketerampilan." Apabila guru menggunakan model pembelajaran langsung ini, gurumempunyai tanggung jawab untuk mengidentifikasikan tujuan pembelajaran dan tanggungjawab yang besar terhadap penstrukturan isi/materi atau keterampilan, menjelaskannyakepada siswa, pemodelan/ mendemonstrasikan yang dikombinasikan dengan latihan,memberikan kesempatan kepada siswa untuk berlatih menerapkan konsep atauketerampilan 
yang telah dipelajari serta memberikan umpan balik (Adnyana, 2006).

\section{B. Metode Demontrasi}

Depdiknas (2009, Modul 3: 34) menjelaskan bahwa pada metode demonstrasi yang perlu diperhatikan adalah proses atau cara kerja sesuatu. Guru memperagakan suatu proses, dimana tidak hanya sekedar untuk dilihat oleh siswa, tetapi dapat dipergunakan untuk mengembangkan suatu pengertian, mengemukakan suatu masalah, memperlihatkan penggunaan suatu prinsip, menguji kebenaran suatu hukum yang diperoleh secara teoiritis dan untuk memperkuat suatu pengertian. Metode ini dapat membuat pelajaran menjadi lebih jelas dan konkrit, sehingga diharapkan dapat dipahami secara lebih mendalam dan bertahan lama dalam pikiran siswa. Pakar lain yang dapat disampaikan pendapatnya tentang metode demonstrasi adalah Winda Gunarti, dkk (2010: 9.3 - 9.8) menjelaskan bahwa metode demonstrasi adalah suatu strategi pengembangan dengan cara memberikan pengalaman belajar melalui perbuatan melihat dan mendengarkan yang diikuti dengan meniru pekerjaan yang didemonstrasikan. Untuk memperagakan serangkaian tindakan berupa gerakan yang menggambarkan suatu cara kerja atau urutan proses sebuah peristiwa atau kejadian. Metode demonstrasi akan memperlihatkan suatu proses atau cara kerja sesuatu, bisa dilakukan melalui dramatisasi. Metode ini membantu peningkatan daya pikir,memperoleh pengalaman belajar.Kelebihannya, membantu anak lebih jelas melihat proses, memudahkan berbagai jenis penjelasan, memusatkan perhatian, dapat mengurangi kesalahan- kesalahanapabila mau mencoba sendiri.Kelemahannya, tidak semua benda atau peristiwa dapat didemonstrasikan, sulit apabila yang mau medemonstrasikan belum mengerti

\section{Prestasi Belajar}

Djamarah

(1994:23)

mendefinisikan prestasi belajar sebagai hasil yang diperoleh berupa kesan-kesan yang mengakibatkan perubahan dalam diri individu sebagai hasil dari aktivitas dalam belajar.Kalau perubahan tingkah laku adalah tujuan yang mau dicapai dari aktivitas belajar, maka perubahan tingkah laku itulah salah satu indikator yang dijadikan pedoman untuk mengetahui kemajuan individu dalam segala hal yang diperolehnya di sekolah. Dengan kata lain prestasi belajar merupakan kemampuankemampuan yang dimiliki oleh siswa sebagai akibat perbuatan belajar atau setelah menerima pengalaman belajar, yang dapat dikatagorikan menjadi tiga ranah, yakni ranah kognitif, afektif, dan psikomotor.

\section{PengertianPenjaskes}

Arti Pendidikan Jasmani :Pendidikan jasmani terdiri dari kata pendidikan dan jasmani, pendidikan adalah proses pengubahan sikap dan tatalaku seseorang atau kelompok orang dalam usaha mendewasakan sesorang atau kelompok orang dalam usaha mendewasakan manusia melalui upaya pengajaran dan latihan (KBBI, 1989), jasmani adalah tubuh atau badan (fisik). Namun yang dimaksud jasmani di sini bukan hanya badan saja tetapi keseluruhan (manusia seutuhnya), karena antara jasmani dan rohani tidak dapat dipisah-pisahkan. Jasmani dan rohanai merupakan satu kesatuan yang utuh yang selalu 
berhubungan dan selalu saling berpengaruah.Pengertian Pendidikan Jasmani Pendidikan Jasamani adalah suatu proses pendidikan seseorang sebagai perseorangan maupun angota masyarakat yang dilakukan secara sadar dan sistematik melalui berbagai kegiatan jasmani dalam rangka memperoleh peningkatan kemampuan dan ketrampilan jasmani, pertumbuhan kecerdasan dan pembentukan watak. Pengertian olahraga adalah suatu bentuk kegiatan jasmani yang terdapat di dalam permainan, perlombaan dan kegiatan intensif dalam rangka memperoleh relevansi kemenangan dan prestasi optimal.Pengertian Olahraga (Menpora Maladi)Olahraga mencakup segala kegiatan manusia yang ditujukan untuk melaksanakan misi hidupnya dan cita-cita hidupnya, citacita nasional politik, sosial, ekonomi, kultural dan sebagainya.Olaharaga rekreasi adalah jenis kegiatan olahraga yang dilakukan pada waktu senggang atau waktu-waktu luang.

\section{Tujuan Pendidikan Penjas orkes}

Pelajaran Jasmani, Olahraga, dan Kesehatan bertujuan agar peserta didik memiliki kemampuan sebagai berikut.

1) Mengembangkan keterampilan pengelolaan diri dalam upaya pengembangan dan pemeliharaan kebugaran jasmani serta pola hidup sehat melalui berbagai aktivitas jasmani dan olahraga yang terpilih.

2) Meningkatkan pertumbuhan fisik dan pengembangan psikis yang lebih baik.

3) Meningkatkan kemampuan dan keterampilan gerak dasar.

4) Meletakkan landasan karakter moral yang kuat melalui internalisasi nilai-nilai yang terkandung di dalam pendidikan jasmani, olahraga, dan kesehatan.

5) Mengembangkan sikap sportif, jujur, disiplin, bertanggung jawab, kerja sama, percaya diri, dan demokratis.

6) Mengembangkan keterampilan untuk menjaga keselamatan diri sendiri, orang lain, dan lingkungan.

7) Memahami konsep aktivitas jasmani dan olahraga di lingkungan yang bersih sebagai informasi untuk mencapai pertumbuhan fisik yang sempurna, pola hidup sehat dan kebugaran .

\section{Kerangka Berpikir}

Pemanfaatan

model

pembelajaran yang cocok dan sesuai untuk diterapkan dalam proses pembelajaran sangat berpengaruh terhadap penguasaan materi oleh peserta didik. Model pembelajaran yang tidak cocok cenderung membuat prestasi belajar rendah.Sesuai dengan hasil yang diperoleh pada observasi atau pengumpulan data awal, peneliti memperoleh hasil yang menunjukkan bahwa masih banyak siswa yang prestasi belajarnya belum mencapai target kriteria ketuntasan belajar yang ditetapkan di sekolah, yaitu sebesar 70,00

Mempertimbangkan begitu pentingnya peranan mata pelajaran pendidikan jasmani olah raga dan kesehatan dalam kehidupan siswa di masa mendatang, sebagai seorang guru yang memiliki rasa tuntutan tugas dan tanggung jawab sebagai pendidik, merasa terpanggil untuk berupaya meningkatkan prestasi belajar 
ADI WIDYA: Jurnal Pendidikan Dasar

Volume. 4, Nomor 1 April 2019

ISSN: 2527-5445

: http://ejournal.ihdn.ac.id/index.php/AW

tersebut agar siswa dapat mencapai hasil sesuai yang diharapkan.

Dari kajian yang peneliti lakukan, diperoleh kesimpulan menyangkut penyebab masalah terletak pada model pembelajaran yang diterapkan belum mampu memotivasi siswa untuk lebih aktif dan kreatif dalam mengikuti proses pembelajaran. Karena itulah guru sebagai peneliti memilih untuk menerapkan model pembelajaran Direct Instruction dengan memanfaatkan metode deomonstrasi untuk mengatasi permasalahan yang dimaksud.

Dengan upaya yang dijelaskan di atas, diharapkan proses pembelajaran akan berjalan lebih aktif dan menyenangkan sehingga dari keaktivan tersebut akan mendorong prestasi belajar siswa dapat mencapai kriteria ketuntasan belajar yang diharapkan.

\section{Hipotesis Tindakan}

Jika model Pembelajaran Direct Instruction dengan metode demonstrasi dilaksanakan secara maksimal maka diduga dapat meningkatkan prestasi belajar pendidikan jasmani olah raga dan kesehatan siswa kelas III semester I tahun Pelajaran 2018/2019 SD Negeri 22 Dauh Puri .

\section{Hasil Penelitian}

1. Siklus I

\section{Rencana Tindakan I}

Perencanaan meliputi:

a) Guru selaku peneliti merencanakan untuk melakukan penelitian dari bulan. Juli sampai bulan oktober 2018 pada semester I b) Guru selaku peneliti merencanakan untuk memperbaiki prestasi belajar Pendidikan jasmani olah raga dan Kesehatan yang masih di bawah KKM memanfaatkan model pembelajaran Derect Intruction dengan Metode Demonstrasi

2. Pelaksanaan Tindakan I

a. Kegiatan Pendahuluan

$>$ Siswa dibariskan menjadi dua barisan

Mengecek kehadiran siswa, memotivasi siswa agar giat belajar, melakukan apersepsi, menyampaikan tujuan pembelajaran

b. Kegiatan inti

> Menyuruh siswa melakukan sesuai contoh yang diberikan.

Mencoba masingmasing siswa agar mampu melakukan

- Memfasilitasi peserta didik melalui pemberian tugas, diskusi dengan teman untuk saling membantu dalam menguasai keterampilan gerak yang benar;

c. Melakukan kegiatan pembelajaran penutup dengan cara:

* Memberikan umpan balik terhadap proses dan hasil pembelajaran;

Menyampaikan rencana pembelajaran pada pertemuan berikutnya; 
Mengakhiri pembelajaran dengan melakukan peregangan.

d. Penutup

Mengakhiri pembelajaran dengan mengucapkan salam penutup.

\section{Observasi/Pengamatan}

\section{Refleksi Siklus I}

Untuk data siklus I dilakukan analisis kuantitatif Prestasi belajar penjas orkes dengan hasil rinci sebagai berikut

1. Rata-rata (mean)

$\frac{\text { Jumlah nilai }}{\text { Jumlah siswa }}=\frac{2794 .}{41}=68,14$

2. Median (titik tengah)

Median yang diperoleh dari data siklus I adalah: 70

3. Modus (angka yang paling banyak/paling sering muncul)

Adalah 71

Untuk persiapan penyajian dalam bentuk grafik maka hal-hal berikut dihitung terlebih dahulu.

1. Banyak kelas $(\mathrm{K})$

Rentang kelas (r) = skor maksimum - skor minimum

Panjang kelas interval (i) $=$ $\frac{r}{K}=\frac{21}{6}=3,5 \rightarrow 4,00$

\section{Siklus II}

\section{Perencanaan}

Perencanaan meliputi:

a) Guru selaku peneliti merencanakan untuk melakukan penelitian dari bulan juli sampai bulan Oktober 2018 pada semester I

b) Guru selaku peneliti merencanakan untuk memperbaiki prestasi belajar Pendidikan jasmani Olah raga dan kesehatan yang masih di bawah KKM memanfaatkan model pembelajaran Derect Intruction dengan metode Demonstrasi .

c) Untuk memperdalam pemahaman tentang model dan metode yang akan diterapkan, guru selaku peneliti melakukan pengkajian beberapa literatur yang sesuai dengan permasalahan yang akan diselesaikan.

d) Menyusun jadwal penelitian, materi, RPP, soal-soal sebagai instrumen untuk mengumpulkan data hasil penelitian.

2. Pelaksanaan Tindakan II Hasil pengamatan pada siklus II

\section{Refleksi Siklus II}

$=1+3,3 \times$ Log Refleksi meyupapakang 41 kajian secara menyeluruh tindakan yang telah dilakukan berdasarkan data yang telah terkumpul, kemudian dilakukan evaltastabuna menyempurnakan tindakan.Refleksi menyangkut analisis, sintesis, dan penilaian terhadap hasil pengamatan atas tindakan yang dilakukan (Hopkin, 1993 dalam Suharsimi Arikunto, Suhardjono, Supardi, 2006: 80).

Analisis kuantitatif Prestasi belajar siswa siklus II

1. Rata-rata (mean) $\frac{\text { Jumlah nilai }}{\text { Jumlah siswa }}=\frac{3120 .}{41}=$ 76,09 
ADI WIDYA: Jurnal Pendidikan Dasar

Volume. 4, Nomor 1 April 2019

ISSN: 2527-5445

2. Median (titik tengah)

Median yang diperoleh

dari data siklus I

dengan menggunakan

cara tersebut adalah:

82,0

3. Modus (angka yang paling banyak/paling sering muncul)

Adalah 79,0

4. Untuk persiapan penyajian dalam bentuk grafik maka hal-hal berikut dihitung terlebih dahulu.

1. Banyak kelas $(\mathrm{K})$

2. Rentang kelas (r)

3. Panjang interval $\frac{r}{K}=\frac{11}{6}=1,83 \rightarrow$ 2,00

4. Tabel 08. Data Kelas Interval Siklus II

\section{Pembahasan}

Hasil tes prestasi belajar yang merupakan tes ketrampilan memforsir siswa untuk betul-betul dapat memahami apa yang sudah dipelajari. Nilai rata-rata siswa di siklus I sebesar 65,68 menunjukkan bahwa siswa setelah menguasai materi yang diajarkan walaupun belum begitu sempurna. Hasil ini menunjukkan peningkatan kemampuan siswa menguasai mata pelajaran pendidikan jasmani olah raga dan kesehatan.Apabila dibandingkan dengan nilai awal siswa sesuai data yang sudah disampaikan dalam analisis sebelumnya.

1. Pembahasan Hasil yang Diperoleh dari Siklus II

Hasil yang diperoleh dari tes prestasi belajar di siklus II
: http://ejournal.ihdn.ac.id/index.php/AW

menunjukkan bahwa kemampuan siswa dalam mengikuti pelajaran sudah cukup baik. Ini terbukti dari rata-rata nilai siswa mencapai 76,09 Hasil ini menunjukkan bahwa model pembelajaran direct instruktion dengan metode demonstrasi telah berhasil meningkatkan prestasi belajar pendidikan olah raga dan kesehatan siswa. Setelah dilakukan tindakan dalam dua siklus dapat dilihat perbandingan nilai rata-rata yang diperoleh, dimana pada $=1+3$, 3walnya nilai rata-rata siswa $=$ skor makya 63.43 naik di. siklus I menjadi 68,14 dan di siklus II naik menjadi 76,09 Kenaikan ini merupakan upayamaksimal yang peneliti laksanakan untuk meningkatkan prestasi belajar siswa terutama meningkatkan mutu pendidikan di SD Negeri 22 Dauh Puri

\section{SIMPULAN}

Dari data awal ada 28 siswa mendapat nilai dibawah KKM dan pada siklus I menurun menjadi 21 siswa dan siklus II hanya 0 siswa mendapat nilai di bawah KKM.

a) Nilai rata-rata awal 63,43 naik menjadi 68,14 pada siklus I dan pada siklus II naik menjadi76,09

b) Dari data awal siswa yang tuntas hanya 13 orang sedangkan pada siklus I menjadi lebih banyak yaitu 20 siswa dan pada siklus II menjadi cukup banyak yaitu 41 siswa.

Dari paparan diatas maka dapat disimpulkan bahwa : model pembelajaran direct Instruction dengan metode demonstrasi dapat 
meningkatkan prestasi belajar pendidikan jasmani olah raga dan kesehatan siswa kelas III semester I tahun pelajaran 2018/2019 di SD Negeri 22 Dauh Puri.

\section{DAFTAR PUSTAKA}

Adnyana, Ida Bagus Putu. 2006.

Jurnal Pendidikan dan

Pengajaran.Pengaruh

Penerapan Strategi

Pembelajaran Inovatif Pada

Pelajaran Biologi Terhadap

Kemampuan Berpikir Kreatif

Siswa SMA. IKIP Negeri

Singaraja, No. 3 TH. XXXIX

Juli 2006.

Aisyah, Siti, dkk. 2008.

Perkembangan dan Konsep

Dasar Pengembangan Anak

Usia Dini. Jakarta:

Universitas Terbuka.

Depdiknas. 2011. Membimbing Guru dalam Penelitian Tindakan Kelas. Jakarta: Pusat Pengembangan Tenaga Kependidikan Badan Pengembangan Sumber Daya Manusia Pendidikan dan Menjaminan Mutu Pendidikan.

Djamarah, Syaful Bahri. 2002. Prestasi Belajar dan Kompetensi Guru. Surabaya: Usaha Nasional.

Kardi S. dan Nur, 2000. Pengajaran Langsung. Penerbit: UnesaUniversity Press. Surabaya.

Kholil, Anwar. 2009. Model Pengajaran Langsung. Tersedia online http://anwarholil.blogspot.co m/2009/01/modelpengajaran-langsung.html

Purwanto, Ngalim. 1997. Psikologi

Pendidikan. Bandung:
: http://ejournal.ihdn.ac.id/index.php/AW

Rosdakarya.

Sardiman, A.M. 1988. Interaksi dan

Motivasi Belajar-Mengajar

Pedoman bagi Guru dan

Calon Guru. Jakarta:

Rajawali Pers.

Slameto. 2003. Belajar dan Faktorfaktor yang Mempengaruhinya. Jakarta: Rineka Cipta

Suhardjono. 2010. Pertanyaan dan Jawaban di Sekitar Penelitian Tindakan Kelas dan Penelitian Tindakan Sekolah. Malang: Cakrawala Indonesia.

Wina Sanjaya. 2006. Strategi Pembelajaran Berorientasi Standar Proses Pendidikan. Kencana Prenada Media: Jakarta.

Yamin, Martinis dan Maisah, 2009. Manajemen Pembelajaran Kelas, Strategi Meningkatkan

PF, K. A. P. D. (2017). The Empowerment Of Role Of The Family In Developing Character Of Environmental Awareness In Elementary School-Age Children. Vidyottama Sanatana: International Journal of Hindu Science and Religious Studies, 1(1), 77-83. 